\title{
Effect of Extracts of Cupressus macrocarpa and Alpinia officinarum on Expression of Chitinase and FGF Receptor Genes in Spodoptera frugiperda Sf9 Cell Line
}

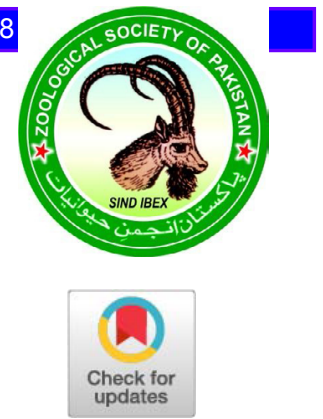

\author{
Hesham M. Abd El Halim, Maysa M. Hegazy ${ }^{1,2}$, Aishah Alatawi ${ }^{3}$, Imtiaz Ali Khan ${ }^{4}$ and \\ Munawar Saleem Ahmad ${ }^{5 *}$
}

${ }^{1}$ Department of Entomology, Faculty of Science, Benha University, Benha, 13518, Egypt.

${ }^{2}$ Department of Biology, Faculty of Science, Jazan University, Jazan, Kingdom of

Saudi Arabia.

${ }^{3}$ Department of Biology, Faculty of Science, University of Tabuk, 71491 Tabuk,

Kingdom of Saudi Arabia.

${ }^{4}$ University of Swabi, Swabi 22621, Khyber Pakhtunkhwa

${ }^{5}$ Department of Zoology, University of Swabi, Swabi 22621, Khyber Pakhtunkhwa

\begin{abstract}
A B S T RA C T
Since plant extracts have long been known to be chitin inhibitor and agents for developmental arrest, chitinase genes and genes that are vital for starting the differentiation program of cells at discrete steps during development are major targets for biocide plant extracts. The current study evaluates the in vitro toxic effects of golden piller (Cupressus macrocarpa) and galangal (Alpinia officinarum) against Spodoptera frugiperda Sf9 cell line. Also, changes in gene expression levels of chitinase genes (SFch$1, \mathrm{SFch}-2$ ) and fibroblast growth factor receptor gene (SFbtl) were demonstrated. Cell sensitivity assay (MTT) showed that golden piller was more toxic than galangal in cell viability tests and more potent in the cell growth inhibition. The calculated $\mathrm{LC}_{50}$ were $120 \mu \mathrm{M}$ and $200 \mu \mathrm{M}$ for golden piller and galangal, respectively. Both plant extracts significantly reduced the gene expression levels of chitinase genes and SFbtl $(\mathrm{p}<0.05)$ following $72 \mathrm{~h}$ of exposure to $\mathrm{LC}_{50}$. This work provides evidence of a viable use of these botanical extracts for pest control as well as highlight the mode of action during the process of chitin formation, degradation and cell proliferation.
\end{abstract}

Article Information
Received 17 July 2019
Revised 12 April 2020
Accepted 07 July 2020
Available online 23 July 2021
Authors' Contribution
HMAEH, MMH and MSA designed
the experiment. HMAEH, MMH,
AA and MSA interpreted the results.
HMAEH, MMH, AA, IAK and MSA
wrote the manuscript. IAK and MSA
corrected the manuscript for final
submission.
Key words
Insect cells, Sf9 cell line, In vitro,
Botanical extracts, Biotechnology,
Gene expression

\section{INTRODUCTION}

$\mathrm{U}$ Ttilization of manufactured chemical pesticides is the most effective method for insect control in agricultural systems (Nauen et al., 2002; Aktar et al., 2009). Despite their viability at controlling insects, there is a genuine need to develop esoteric methodologies with lower environmental and non-target impacts (Ware and Whitacre, 2004). Biopesticides are an important group of naturally occurring, often slow-acting crop protectants that are generally more secure to people and nature than ordinary pesticides, and with insignificant leftover impacts (Akhtar et al., 2008). Biopesticides can be biochemical or microbial. Biochemical pesticides may incorporate plantderived pesticides (botanicals) that can meddle with the

\footnotetext{
* Corresponding author: saleemsbs@gmail.com, saleemsbs@uoswabi.edu.pk 0030-9923/2021/0005-1829 \$ 9.00/0

Copyright 2021 Zoological Society of Pakistan
}

development, feeding, or reproduction of pests or insect pheromones connected for mating interruption (Kabiri and Amiri-Besheli, 2012).

Over the past decades different industries have exhibited an expanded interest to create in vitro strategies to examine insecticide effects. Such methods are considered recently potential alternatives to conventional animal toxicity tests (Eisenbrand et al., 2002). They further diminish the requirement for tedious and exorbitant tests performed utilizing live animals or isolated organs (Barlow et al., 2002).

Spodoptera frugiperda was not found in Asia and was limited to America and some other western countries. In 2019 it is reported in India and it is expected that it will reach and colonize neighbouring countries. It can reach Middle East. So this threat must be taken seriously and preparations should be made to cope with it (Firake and Behere, 2020). The commercially available Sf9 insect cell line derived from pupal ovarian tissue of $S$. frugiperda was used for in vitro assays to estimate the effect of 
different insecticides, and to test the effect of fungal metabolites, or the effect of some insect fungi that could be developed as biopesticides. Sf9 cell line was additionally used to contemplate Bacillus thuringiensis poisons and to investigate their mode of action (Saleh et al., 2013). Botanical pesticides are plant derivatives that repel, inhibit and interfere with physiological activities or destroy pests (Hikal et al., 2017). Moreover, the production of essential enzymes such as those responsible for moulting often interferes with botanical pesticides, which inhibits growth and development (Ogah, 2013). In general, plant extracts have long been known to be chitin inhibitor and causing developmental arrest (Ghoneim, 2020). Chitin is one of the most important biopolymers in nature (Zhang et al., 2017). In insects, it is playing a canonical key role for supporting the cuticles of the epidermis, trachea, peritrophic membrane and lining the gut epithelium as scaffolding material (Kumar et al., 2018). Insect growth and morphogenesis are strictly dependent on the capability to rebuild chitin containing structures, thus, insects repeatedly produce chitin synthases and Chitodextrinase enzymes in different tissues (Muthukrishnan et al., 2016). Chitin synthesis and degradation requires strict control of the participating enzymes during development. All insect chitinases belonging to family 18 glycosylhydrolases have been detected in moulting fluid and gut tissues, furthermore, anticipated to the digestion of chitin present in the exoskeleton and peritrophic membrane in the gut to chitooligosaccharides (Brent et al., 2016). Insect's chitinases homologues genes have been characterized and described from several insects including lepidopteran species (Kramer et al., 1993; Zhu et al., 2008; Zhuo et al., 2014; Shi et al., 2016).

Although, Fibroblast Growth Factors (FGFs) were first found in mammals, the discovery of the first FGF receptor (FGFR) gene in Drosophila melanogaster proposing that FGF signalling is evolutionary conserved and opened up the horizon of insect FGF research (Klingseisen et al., 2009; Muha and Müller, 2013). The Drosophila genome encodes just two FGFRs, which are implicated in comparative cell settings as in vertebrates, for example, proliferation, cell survival, differentiation and cell migration (Kadam et al., 2012). As a rule FGF signalling focuses on the transcription of genes that are vital for starting the differentiation program of cells at discrete steps during development (Avet-Rochex et al., 2012; Stork et al., 2014).

The objective of this investigation was to test the lethal impact of two botanical extracts, golden piller (Cupressus macrocarpa) and galangal (Alpinia officinarum) using a cultured Sf9 insect cell line and MTT test to quantitatively evaluate cell proliferation during exposure to the selected botanical extracts. Furthermore, demonstrate the expression level of SFch-1, SFch-2 (chitinase genes) and SFbtl (Fibroblast growth factor receptor gene) after $72 \mathrm{~h}$. of exposure to $\mathrm{LC}_{50}$.

\section{MATERIALS AND METHODS}

\section{Tested plants}

The plants under examinations were initially acquired from Egypt. Quickly, the plant oils were separated by steam distillation using $300 \mathrm{~g}$ of plants in $300 \mathrm{ml}$ of water for 4-6h. following the depicted strategy by (Marcus and Lichtenstein, 1979; Weaver et al., 1994). Oils were put away in dull glass bottles in the fridge until use.

\section{Spodoptera frugiperda Sf9 cells}

The Sf9 cells got from pupal ovarian tissue of $S$. frugiperda were bought from Invitrogen (Catalog no. B825-01). Cells were kept up at $27^{\circ} \mathrm{C}$ in $25 \mathrm{~cm}^{2}$ culture flasks in $5 \mathrm{ml}$ without serum culture mediumSF-900 II SFM Invitrogen (Catalog no. 10902-096). Monolayer shaped cells were sub refined each 3-4 days in the wake of segregating utilizing a scraper.

\section{Cell sensitivity assay (MTT)}

Sub cultured cells were gathered six days after sub refined and diluted with fresh medium to a thickness of $7.5 \times 10^{4}$ cells $/ \mathrm{ml}$. Each well of a 96-well microtiter culture plate was stacked with $100 \mu$ l of cell solution containing $5 \mu \mathrm{l}$ of the tested compound solution. The final concentration range of botanical extracts was 0.4 to $500 \mu \mathrm{M}$. Each concentration tested consisted of three duplicates and the test was rehashed twice. Cell sensitivity assay (MTT) was performed after $72 \mathrm{~h}$ of exposure as described by Borenfreund et al. (1988). The test medium was supplemented with $20 \mu \mathrm{l}$ of $2 \mathrm{mg} / \mathrm{ml}$ MTT dissolved in cell culture medium SF-900 II SFM, following overnight staining at $27{ }^{\circ} \mathrm{C}$, the staining solution was carefully removed and to solubilise the purple formazan crystals produced within the cell $150 \mu 1 /$ well dimethylsulphoxide (DMSO) was added. The absorbance of each well was estimated at $540 \mathrm{~nm}$ using a microplate reader. Cell growth was expressed as a percentage of absorbance ratio: Absorbance in wells with botanical extracts treatment to control well (cells treated with zero concentration of botanical extracts). The inhibition rate (IR) was determined according to (Liu et al., 2010).

IR. $=(1-\mathrm{At} / \mathrm{Ac}) \times 100$

At: absorbance value of tested wells.

Ac: absorbance value of control wells.

\section{Selection of target genes}

Detection of the target genes used in the present 
investigation was done by using UniProt website (http:// www.uniprot.org/), output showed two genes of $S$. frugiperda related to chitinase identified as SFch-1 [NCBI Reference Sequence: AY525599.1], and SFch-2 [NCBI Reference Sequence AY527414.1]. Likewise, one gene of $S$. frugiperda related to Fibroblast growth factor receptor identified as SFbtl [NCBI Reference Sequence: AB247567.1].

\section{RNA extraction and reverse transcriptase ( $R T-P C R)$}

Total RNA was isolated from a pellet of cultured cells using an RNeasy Plus minikit (Qiagen, Cat No./ID: 74134) following the manufacturer's protocol. RNA integrity was evaluated on 1.5\% agarose gel as described in (Sambrook, 2001), and quantified spectrophotometrically (NanoDrop, Labtech, ND-1000). cDNA syntheses was performed using i-Script ${ }^{\mathrm{TM}}$ reverse transcription supermix for RT-qPCR kit (BIO-RAD, Cat No./ID:170-8841).

\section{Gene expression studies with (RT-qPCR)}

cDNA prepared as explained in section above was used as a template. RT-qPCR was performed on the template in a final volume of $25 \mu \mathrm{l}$. Each reaction contained: $12.5 \mu 12 \mathrm{x}$ Rotor-gene SYBR green PCR master mix solution (Qiagen Co.), forward and reverse primers (Table I) were added in a final concentration of $0.5 \mathrm{mM}, 9 \mu \mathrm{l}$ nuclease free water and $1 \mu 1$ of undiluted cDNA. To approve the primers, a standard curve dependent on a serial dilution of cDNA was done to determine the primer annealing efficiency, the presence of primer dimers and the production of a single PCR product. RT-qPCR conditions were as follows: $95{ }^{\circ} \mathrm{C}$ for $5 \mathrm{~min}$, followed by 40 cycles of $95{ }^{\circ} \mathrm{C}$ for $15 \mathrm{sec}$., $55^{\circ} \mathrm{C}$ for 30 sec. and $60^{\circ} \mathrm{C}$ for $15 \mathrm{sec}$. Amplifications were carried out using three biological replicates of cDNA, and the mean values of three technical replicates were analyzed. The efficiency of the primers were equivalent and the relative transcript quantity was calculated according to the deltadelta $\mathrm{Ct}$ method (Livak and Schmittgen, 2001), with $\mathrm{Ct}$ values of the respective target gene compared to those of the reference gene Actin (GenBank KT218672); this gene is a reliable reference gene for RT-qPCR in $S$. frugiperda (Mehrabadi et al., 2013), and hence used to normalize gene expression.

\section{Statistical analysis}

Analysis of probit regression was applied to estimate the $50 \%$ inhibition of cell growth, $\mathrm{LC}_{50}$ was calculated using Microsoft excel 2010. Linear regression analysis of doseresponse data was performed to obtain the mathematical curve. Experimental data and qPCR results were analysed by ANOVA followed by Tukey Kramer Multiple Comparison; statistical differences are shown as different letters.

\section{RESULTS}

The tested botanical extracts significantly $(\mathrm{p}<0.05)$ inhibited cell growth. The concentrations of insecticides resulting in $50 \%$ inhibition of cell growth were: $120 \mu \mathrm{M}$, and $200 \mu \mathrm{M}$ for golden piller and galangal respectively (Table II), and R2=0.9. Relative potency and toxicity index $\%$ (Table II) were calculated according to (Sun, 1950). Effect was determined by MTT assay. The percentage of cells mortality was plotted against the tested concentrations and the $\mathrm{LC}_{50}$ values were determined, the response was dose-dependent, i.e. the cells mortality increases with the increase of the concentration.

Table I. Primers used in performing qRT-PCR.

\begin{tabular}{lll}
\hline Gene & Primer sequence (5-3) & Amplicon size \\
\hline SFch-1 & TGTTCCTCCTGTTCTTCGGC & $98 \mathrm{bp}$ \\
& CTTGGTGGTGGACAGCAGAT & \\
SFch-2 & GCAATTGAAGCGGACAGCAA & $97 \mathrm{bp}$ \\
& GGATGTCCTCGATGCCGTAG & \\
SFbtl & AGAACACGACGAGCGATTCA & $94 \mathrm{bp}$ \\
& TTCCCAATGCACAGGGAGTC & \\
Actin & ACGCCACGGTCTAGTTGAAG & $94 \mathrm{bp}$ \\
& ATGGTGATCTTCGGGTTCCG & \\
\hline
\end{tabular}

Table II. Toxicity and relative potency against $\mathrm{Sf} 9$ cell lines.

\begin{tabular}{|c|c|c|c|c|c|}
\hline \multirow[t]{2}{*}{$\begin{array}{l}\text { Concen- } \\
\text { trations } \\
(\mu \mathrm{M})\end{array}$} & \multirow[t]{2}{*}{$\begin{array}{l}\text { Control } \\
\text { without } \\
\text { treatment }\end{array}$} & \multirow[t]{2}{*}{$\begin{array}{l}\text { Golden } \\
\text { piller }\end{array}$} & \multirow[t]{2}{*}{$\begin{array}{l}\text { Galan- } \\
\text { gal }\end{array}$} & \multicolumn{2}{|c|}{$\begin{array}{l}\text { Relative potency and } \\
\text { toxicity index \%* } \\
\text { based on }\end{array}$} \\
\hline & & & & $\begin{array}{l}\text { Golden } \\
\text { piller }\end{array}$ & Galangal \\
\hline \multirow[t]{2}{*}{$\mathrm{LC}_{50}$} & 0.0 & $120 \mu \mathrm{M}$ & $200 \mu \mathrm{M}$ & 1 & 0.6 \\
\hline & & & & 1.7 & 1 \\
\hline
\end{tabular}

*Toxicity index $=\mathrm{LC}_{50}$ or $\mathrm{LC}_{90}$ of the efficient compound / $\mathrm{LC}_{50}$ or $\mathrm{LC}_{90}$ of the other compound $\times 100$

Down-regulation of SFch-1 following $72 \mathrm{~h}$ of exposure to $\mathrm{LC}_{50}$ of the tested compounds were demonstrated using RT-qPCR (Fig. 1A). Analysis showed a decrease in the abundance of SFch-1mRNA transcript. Gene downregulation was shown to be significant $(p<0.05)$ with expression of SFch-1 being reduced with -1.43 and -2 fold in response to treatment with $120 \mu \mathrm{M}$, and $200 \mu \mathrm{M}$ for golden piller and galangal, respectively, relative to control without treatment.

Furthermore, qPCR analysis revealed that SFch-2 mRNA transcript levels was also significantly $(p<0.05)$ 
down regulated following $72 \mathrm{~h}$ of exposure to $\mathrm{LC}_{50}$ of the tested compounds (Fig. 1B). The abundance of SFch2 mRNA transcript being -1.47 and -1.75 fold lower, respectively for golden piller and galangal, relative to control without treatment.

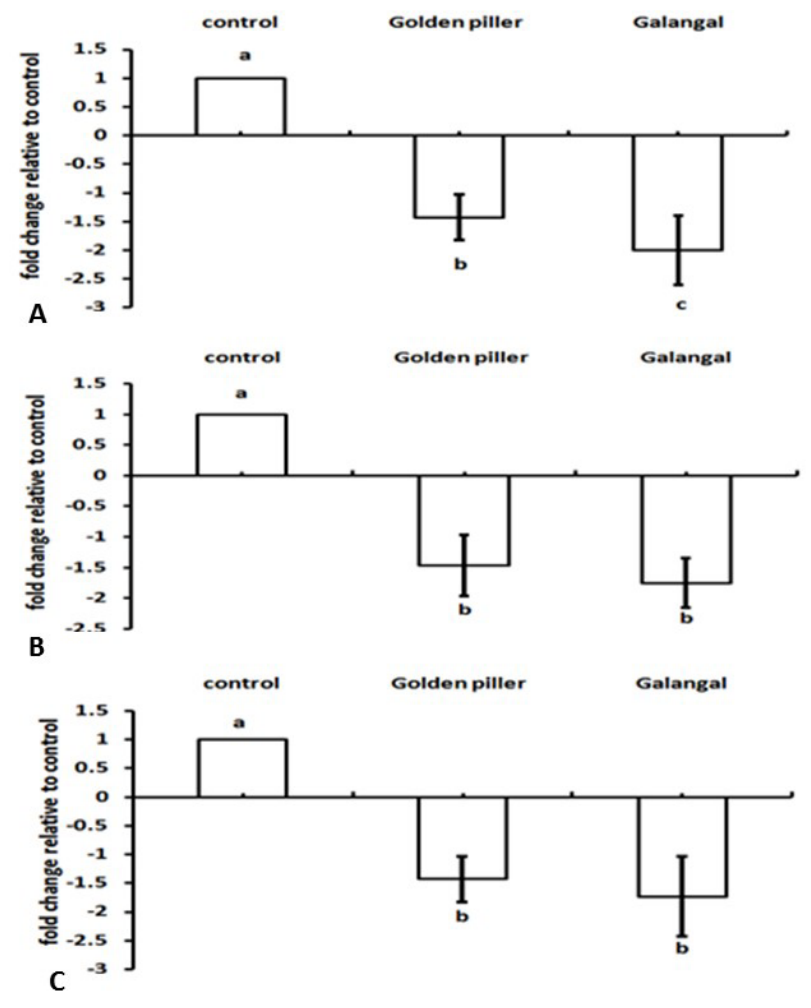

Fig. 1. Transcript levels after normalization with Actin gene as an endogenous control $72 \mathrm{~h}$ post treatment. (A) SFch-1 mRNA, (B) SFch-2 mRNA, (C) SFbtl mRNA. Mean \pm SEM of three replications are shown. Means with the different letters are significantly different $(p=0.05$; ANOVA; with Tukey Kramer Multiple Comparison).

Not only did exposure to $\mathrm{LC}_{50}$ of the tested compounds cause down regulation of SFch-1 and SFch-2 genes, there was also evidence that SFbtl gene was down regulated (Fig. 1C). qPCR analysis revealed that after $72 \mathrm{~h}$ of exposure transcript levels were significantly $(\mathrm{p}<$ 0.05 ) down regulated by -1.43 and -1.73 fold, respectively for golden piller and galangal, relative to control without treatment.

\section{DISCUSSION}

The broad utilization of the manufactured chemical insecticides cause biological imbalance due to disruption of beneficial species such as parasites and predators beside the loss of pollinating insects such as honey bees. Plant derivatives and natural products of plants are great options in contrast to synthetic insecticides currently used for insect control because they constitute rich sources of bioactive chemicals (Gahukar, 2014). Plant-derived materials are observed to be very effective against insecticide resistant insect pests, moreover, they are biodegradable (Velasques et al., 2017).

Chitin is a polymer of $\mathrm{N}$-acetylglucosamine, accounts for about 3-13\% (w/w) of the insect dry weight (GrifollRomero et al., 2018). It works as platform material, supporting the cuticles of the epidermis and trachea as well as the peritrophic matrices coating the gut epithelium (Kelkenberg et al., 2015). Some insecticides target processes unique to insects, such as the biosynthesis of chitin, an intense, semitransparent polysaccharide that is the fundamental component of the insect's exoskeleton, key insecticide target groups include insect growth regulators.

Cell differentiation and cell movements during the development of multicellular animals is controlled by intercellular signalling via growth factors (Sun and Stathopoulos, 2018). Several studies argue that FGF signalling is used in multi-step morphogenetic processes to achieve and maintain a transitional state of the cells required for the control of cell fate. These FGF receptors affect gene expression, cell shape and cell-cell interactions during mesoderm layer formation, caudal visceral muscle (CVM) formation, tracheal morphogenesis and glia differentiation (Burguera et al., 2017).

The botanical extracts tested proved to be strong cell growth inhibitor. Data obtained in this context clearly demonstrated that golden piller is more toxic and potent than galangal, a likely explanation, may be due to variation of the photochemical structure of these oils (Obeng-Ofori et al., 1997; Tapondjou et al., 2005). previous work done by (Khalaf et al., 2009) showed that golden piller rich in alpha pinene (67.94\%) and trans-caryophyllene (5.10\%), while galangal rich in 1,8-cineole $(72.33 \%)$ and 4-terpeniol (3.61\%). Although, isolated compounds from the 2 oils are terpenoids, monoterpene and sesquiterpene, the number of methyl and hydroxyl groups in golden piller is greater than galangal (Khalaf et al., 2009), this could give another likely explanation of the higher toxicity of golden piller than galangal (Khalaf et al., 2009; Regnault-Roger et al., 2012).

Exposure to $\mathrm{LC}_{50}$ of the tested botanical extracts induced quantifiable effects, resulting in reduction of gene expression after 72h RT-qPCR analysis, showed that transcript levels for SFch-1 and SFch-2 genes were down-regulated. Likely explanation, may be due to those 2 volatile oils belong to terpen group and may act as IGRs or juvenoids (Tripathi, 1998; Tawatsin et al., 2006). The 
obtained results in this context were in agreement with the findings of many authors tested different plant extracts against various insects and they found severe damage in the integument, cuticular abnormalities, lack of differentiation between exocuticle and endocuticle, destruction of the basement membrane and appearance of vacuoles between cuticle and hypodermis and detachment of cuticle from hypodermis (Hashem et al., 2018). Moreover, downregulation of SFbtl (Fibroblast growth factor receptor gene) was observed after exposure to $\mathrm{LC}_{50}$ of the tested botanical extracts. Thus the reduction in SFbtl gene expression could give a likely explanation for inhibition of cell growth in this study, as the Fibroblast growth factor receptor control cell fate as well as proliferation, cell survival, differentiation and cell migration (Sharma et al., 2015; Burguera et al., 2017). Although statistically significant changes in expression were detected, the levels of down-regulation were low and might indicate another mechanism for the toxicity of these extracts. Some more work using illumina RNA-seq to demonstrate and understand the relationship between gene expression level and the exact mechanism with other genes and pathways should be done.

\section{CONCLUSION}

In conclusion, the outcomes introduced in this context, not just feature the mode of action of the tested botanical extracts during the process of chitin formation and degradation in $S$. frugiperda $\mathrm{Sf} 9$ cell line, it likewise gives another clarification for bioassays obtained results and malformations, and demonstrate the feasibility to develop bioassays to screen target genes for the construction of transgenic plants and bio-insecticides for pest control.

\section{Statement of conflict of interest}

The Authors have declared no conflict of interest.

\section{REFERENCES}

Akhtar, Y., Yeoung, Y.-R. and Isman, M., 2008. Comparative bioactivity of selected extracts from meliaceae and some commercial botanical insecticides against two noctuid caterpillars, Trichoplusia $n i$ and Pseudaletia unipuncta. Phytochem. Rev., 7: 77-88. https://doi.org/10.1007/ s11101-006-9048-7

Aktar, W., Sengupta, D. and Chowdhury, A., 2009. Impact of pesticides use in agriculture: Their benefits and hazards. Interdiscip. Toxicol., 2: 1-12. https://doi.org/10.2478/v10102-009-0001-7

Avet-Rochex, A., Kaul, A.K., Gatt, A.P., McNeill,
H. and Bateman, J.M., 2012. Concerted control of gliogenesis by inr/tor and fgf signalling in the drosophila post-embryonic brain. Development (Cambridge, Engl.), 139: 2763-2772. https://doi. org/10.1242/dev.074179

Barlow, S., Greig, J., Bridges, J., Carere, A., Carpy, A., Galli, C.L., Kleiner, J., Knudsen, I., Koeter, H. and Levy, L., 2002. Hazard identification by methods of animal-based toxicology. Fd. Chem. Toxicol., 40: $145-191 . \quad$ https://doi.org/10.1016/S02786915(01)00117-X

Borenfreund, E., Babich, H. and Martin-Alguacil, N., 1988. Comparisons of two in vitro cytotoxicity assays the neutral red (nr) and tetrazolium mtt tests. Toxicol. In Vitro, 2: 1-6. https://doi. org/10.1016/0887-2333(88)90030-6

Brent, C.S., Wang, M., Miao, Y.G. and Hull, J.J., 2016. Ecdysteroid and chitinase fluctuations in the western tarnished plant bug (Lygus hesperus) prior to molt indicate roles in development. Arch. Insect Biochem. Physiol., 92: 108-126. https://doi. org/10.1002/arch.21322

Burguera, D., Marquez, Y., Racioppi, C., Permanyer, J., Torres-Méndez, A., Esposito, R., AlbuixechCrespo, B., Fanlo, L., D’Agostino, Y. and Gohr, A., 2017. Evolutionary recruitment of flexible esrpdependent splicing programs into diverse embryonic morphogenetic processes. Nat. Commun., 8: 1799. https://doi.org/10.1038/s41467-017-01961-y

Eisenbrand, G., Pool-Zobel, B., Baker, V., Balls, M., Blaauboer, B., Boobis, A., Carere, A., Kevekordes, S., Lhuguenot, J.-C. and Pieters, R., 2002. Methods of in vitro toxicology. Fd. Chem. Toxicol., 40: 193-236. https://doi.org/10.1016/S02786915(01)00118-1

Firake, D. and Behere, G., 2020. Natural mortality of invasive fall armyworm, Spodoptera frugiperda (je smith) (lepidoptera: Noctuidae) in maize agroecosystems of northeast india. Biol. Contr., 148: 104303. https://doi.org/10.1016/j. biocontrol.2020.104303

Gahukar, R., 2014. Factors affecting content and bioefficacy of neem (Azadirachta indica a. Juss.) phytochemicals used in agricultural pest control: A review. Crop Protec., 62: 93-99. https://doi. org/10.1016/j.cropro.2014.04.014

Ghoneim, K., 2020. Impairing effectiveness of nerolidol, a sesquiterpene compound, on adult performance and reproductive potential of egyptian cotton leafworm, Spodoptera littoralis (Lepidoptera: Noctuidae). Egypt. Acad. J. biol. Sci., 13: 97-120. https://doi.org/10.21608/eajbsa.2020.80074 
Grifoll-Romero, L., Pascual, S., Aragunde, H., Biarnés, X. and Planas, A., 2018. Chitin deacetylases: Structures, specificities, and biotech applications. Polymers, 10: 352. https://doi.org/10.3390/ polym 10040352

Hashem, A.S., Awadalla, S.S., Zayed, G.M., Maggi, F. and Benelli, G., 2018. Pimpinella anisum essential oil nanoemulsions against Tribolium castaneum insecticidal activity and mode of action. Environ. Sci. Pollut. Res., 25: 18802-18812. https://doi. org/10.1007/s11356-018-2068-1

Hikal, W.M., Baeshen, R.S. and Said-Al-Ahl, H.A., 2017. Botanical insecticide as simple extractives for pest control. Cogent Biol., 3: 1404274. https:// doi.org/10.1080/23312025.2017.1404274

Kabiri, M. and Amiri-Besheli, B., 2012. Toxicity of palizin $($, mospilan $(\mathbb{C}$ and consult $(\mathrm{C}$ on Agonoscena pistaciae burckhardt and lauterer (Hemiptera: Psyllidae), Oenopia conglobata L. (Coleoptera: Coccinellidae) and Psyllaephagus pistaciae ferrière (hymenoptera: Encyrtidae). Acad. J. Ent., 5: 99-107.

Kadam, S., Ghosh, S. and Stathopoulos, A., 2012. Synchronous and symmetric migration of drosophila caudal visceral mesoderm cells requires dual input by two fgf ligands. Development (Cambridge Engl.), 139: 699-708. https://doi. org/10.1242/dev.068791

Kelkenberg, M., Odman-Naresh, J., Muthukrishnan, S. and Merzendorfer, H., 2015. Chitin is a necessary component to maintain the barrier function of the peritrophic matrix in the insect midgut. Insect Biochem. Mol. Biol., 56: 21-28. https://doi. org/10.1016/j.ibmb.2014.11.005

Khalaf, A.F.A., Hussein, K.T. and Shoukry, K.K., 2009. Biocidal activity of two botanical volatile oils against the larvae of Synthesiomyia nudiseta (Wulp) (Diptera: Muscidae). Egypt. Acad. J. biol. Sci., 2: 89-101. https://doi.org/10.21608/ eajbsa.2009.15496

Klingseisen, A., Clark, I.B., Gryzik, T. and Müller, H.A.J., 2009. Differential and overlapping functions of two closely related drosophila fgf8-like growth factors in mesoderm development. Development (Cambridge, Engl.), 136: 2393-2402. https://doi. org/10.1242/dev.035451

Kramer, K.J., Corpuz, L., Choi, H.K. and Muthukrishnan, S., 1993. Sequence of a cDNA and expression of the gene encoding epidermal and gut chitinases of Manduca sexta. Insect Biochem. Mol. Biol., 23: 691-701. https://doi.org/10.1016/09651748(93)90043-R
Kumar, M., Vivekanand, V. and Pareek, N., 2018. Structure, regulation, and potential applications of insect chitin-metabolizing enzymes. In: Trends in insect molecular biology and biotechnology (eds. D. Kumar and C. Gong). Springer International Publishing, Cham. pp. 295-316. https://doi. org/10.1007/978-3-319-61343-7_14

Liu, J.-W., Cai, M.-X., Xin, Y., Wu, Q.-S., Ma, J., Yang, P., Xie, H.-Y. and Huang, D.-S., 2010. Parthenolide induces proliferation inhibition and apoptosis of pancreatic cancer cells in vitro. J. exp. Clin. Cancer Res., 29: 108. https://doi.org/10.1186/1756-996629-108

Livak, K.J. and Schmittgen, T.D., 2001. Analysis of relative gene expression data using real-time quantitative pcr and the 2(-delta delta $\mathrm{c}(\mathrm{t}))$ method. Methods, 25: 402-408. https://doi.org/10.1006/ meth.2001.1262

Marcus, C. and Lichtenstein, E.P., 1979. Biologically active components of anise: Toxicity and interactions with insecticides in insects. J. Agric. Fd. Chem., 27: 1217-1223. https://doi.org/10.1021/ jf60226a077

Mehrabadi, M., Hussain, M. and Asgari, S., 2013. Micrornaome of Spodoptera frugiperda cells (sf9) and its alteration following baculovirus infection. $J$. Gen. Virol., 94: 1385-1397. https://doi.org/10.1099/ vir.0.051060-0

Muha, V. and H.-A.J. Müller, 2013. Functions and mechanisms of fibroblast growth factor (fgf) signalling in Drosophila melanogaster. Int. J. mol. Sci., 14: 5920-5937. https://doi.org/10.3390/ ijms 14035920

Muthukrishnan, S., Merzendorfer, H., Arakane, Y. and Yang, Q., 2016. Chitin metabolic pathways in insects and their regulation. In: Extracellular composite matrices in arthropods (eds. B. Cohen and B. Moussian). Springer International Publishing, Cham. pp. 31-65. https://doi.org/10.1007/978-3319-40740-1_2

Nauen, R., Stumpf, N. and Elbert, A., 2002. Toxicological and mechanistic studies on neonicotinoid cross resistance in q-type Bemisia tabaci (Hemiptera: Aleyrodidae). Pest Manage. Sci., 58: 868-875. https://doi.org/10.1002/ps.557

Obeng-Ofori, D., Reichmuth, C., Bekele, J. and Hassanali, A., 1997. Biological activity of 1, 8 cineole, a major component of essential oil of Ocimum kenyense (ayobangira) against stored product beetles. J. appl. ent., 121: 237-243. https:// doi.org/10.1111/j.1439-0418.1997.tb01399.x

Ogah, E.O., 2013. Field evaluation of plant extracts in 
the management of Megalurothrips sjostedti and Maruca vitrata of cowpea in southeastern Nigeria. World Essays J., 1: 11-17.

Regnault-Roger, C., Vincent, C. and Arnason, J.T., 2012. Essential oils in insect control: Low-risk products in a high-stakes world. Annu. Rev. Ent., 57: 405-424. https://doi.org/10.1146/annurevento-120710-100554

Saleh, M., Hajjar, J. and Rahmo, A., 2013. Effect of selected insecticides on sf9 insect cell line. Leban. Sci. J., 14: 115.

Sambrook, J., 2001. Molecular cloning: a laboratory manual, $3^{\text {rd }}$ ed. Cold Spring Harbor Laboratory Press, Cold Spring Harbor, N.Y.

Sharma, R., Beer, K., Iwanov, K., Schmöhl, F., Beckmann, P.I. and Schröder, R., 2015. The single fgf receptor gene in the beetle Tribolium castaneum codes for two isoforms that integrate fgf8-and branchless-dependent signals. Dev. Biol., 402: 264 275. https://doi.org/10.1016/j.ydbio.2015.04.001

Shi, J.F., Mu, L.L., Guo, W.C. and Li, G.Q., 2016. Identification and hormone induction of putative chitin synthase genes and splice variants in Leptinotarsa decemlineata (Say). Arch. Insect Biochem. Physiol., 92: 242-258. https://doi. org/10.1002/arch.21331

Stork, T., Sheehan, A., Tasdemir-Yilmaz, O.E. and Freeman, M.R., 2014. Neuron-glia interactions through the heartless fgf receptor signaling pathway mediate morphogenesis of Drosophila astrocytes. Neuron, 83: 388-403. https://doi.org/10.1016/j. neuron.2014.06.026

Sun, J. and Stathopoulos, A., 2018. Fgfcontrols epithelialmesenchymal transitions during gastrulation by regulating cell division and apicobasal polarity. Development (Cambridge Engl.), pp. 161927. https://doi.org/10.1242/dev.161927

Sun, Y.-P., 1950. Toxicity index-an improved method of comparing the relative 378 toxicity of insecticides. J. econ. Ent., 43: 45-53. https://doi.org/10.1093/ jee/43.1.45

Tapondjou, A., Adler, C., Fontem, D., Bouda, H. and Reichmuth, C., 2005. Bioactivities of cymol and essential oils of Cupressus sempervirens and Eucalyptus saligna against Sitophilus zeamais motschulsky and Tribolium confusum du val. J. Stored Prod. Res., 41: 91-102. https://doi. org/10.1016/j.jspr.2004.01.004
Tawatsin, A., Asavadachanukorn, P., Thavara, U., Wongsinkongman, P., Bansidhi, J., Boonruad, T., Chavalittumrong, P., Soonthornchareonnon, N., Komalamisra, N. and Mulla, M.S., 2006. Repellency of essential oils extracted from plants in thailand against four mosquito vectors (Diptera: Culicidae) and oviposition deterrent effects against Aedes aegypti (Diptera: Culicidae). Southeast Asian J. Trop. Med. Public Hlth., 37: 915.

Tripathi, Y., 1998. Phytopesticides, an ecofriendly approach for pest control. Ind. J. environ. Sci., 2: 63-71.

Velasques, J., Cardoso, M.H., Abrantes, G., Frihling, B.E., Franco, O.L. and Migliolo, L., 2017. The rescue of botanical insecticides: A bioinspiration for new niches and needs. Pestic. Biochem. Physiol., 143: 14-25. https://doi.org/10.1016/j. pestbp.2017.10.003

Ware, G.W. and Whitacre, D.M., 2004. An introduction to insecticides. MeisterPro information resources, a division of Meister media worldwide, $4^{\text {th }}$ edn. Willoughby, Ohio, USA.

Weaver, D.K., Wells, C.D., Dunkel, F.V., Bertsch, W., Sing, S.E. and Sriharan, S., 1994. Insecticidal activity of floral, foliar, and root extracts of Tagetes minuta (Asterales: Asteraceae) against adult mexican bean weevils (Coleoptera: Bruchidae). $J$. econ. Ent., 87: 1718-1725. https://doi.org/10.1093/ jee/87.6.1718

Zhang, L., Qiu, L.-Y., Yang, H.-L., Wang, H.-J., Zhou, M., Wang, S.-G. and Tang, B., 2017. Study on the effect of wing bud chitin metabolism and its developmental network genes in the brown planthopper, Nilaparvata lugens, by knockdown of TRE gene. Front. Physiol., 8: 750. https://doi. org/10.3389/fphys.2017.00750

Zhu, Q., Arakane, Y., Banerjee, D., Beeman, R.W., Kramer, K.J. and Muthukrishnan, S., 2008. Domain organization and phylogenetic analysis of the chitinase-like family of proteins in three species of insects. Insect Biochem. mol. Biol., 38: 452-466. https://doi.org/10.1016/j.ibmb.2007.06.010

Zhuo, W., Fang, Y., Kong, L., Li, X., Sima, Y. and Xu, S., 2014. Chitin synthase a: A novel epidermal development regulation gene in the larvae of Bombyx mori. Mol. Biol. Rep., 41: 4177-4186. https://doi.org/10.1007/s11033-014-3288-1 